\title{
CROSS CULTURAL COMMUNICATION IN TELL IT TO THE TRESS BY ANITA RAU BADAMI
}

\section{Dr. Priyanki R Vyas \\ Dr. Mahesh B Bhatt Ms. Jill Joshi}

\begin{abstract}
In the era of globalization, migration has become inevitable for progress and sustenance. The liberalization policy of Canada towards immigration has made it possible for a large number of Indians to settle in Canada. The writers of Diaspora enable a reader to peep into the culture of both -the hostland and the homeland. The study of writings of Diaspora leads towards better understanding of the opportunities, issues and challenges of the nations and provides hint to attain progress through harmony between the nations.

Anita Rau Badami is a writer of South Asian Diaspora living in Canada with a strong voice of the modern Indian Diaspora. Born in Rourkela, Odisha, India, she migrated to Canada in 1991. Her novels deal with the complexities of Indian family life and with the cultural gap that emerges when Indians move to the west. Anita Rau Badami narrates two world viz. Canada and India as perceived by the characters in the novel. Indian representation viz. colonial set up, poverty stricken communities, patriarchal set up, socio- religious rituals etc. are portrayed. Canadian culture is both -a real hand experience by the immigrants as well as the myth/imagination of their relatives in India.

Tell It to the Trees is a story about a dysfunctional family of East Indian immigrants whose burden of secrets spells disaster for them and others. The story centers around the Dharma family, headed by Vikram Dharma who lives in the house that his father, Mr. J.K. Dharma, built years ago in the isolated wilds of Merrit's Point,
\end{abstract}


British Columbia. The novel will be evaluated from the cultural studies point of view with the theories of Edward Said and Gayatri Spivak on legacy of colonialism. The cross cultural study of literary text enables to know about the differences between the cultures of India and Canada and helps for an effective and long-standing partnership between India and Canada.

KEY WORDS: Diaspora, Culture, Colonialism, memory

${ }^{*}$ Corresponding Author

\section{Globalization, Diaspora and Culture}

The movement of people across national borders, referred to as international migration, is viewed as a "global challenge for the $21^{\text {st }}$ century" (Martin and Widgren 3).As emphasized by Croucher, migration "is a complex social, political and economic issue that poses numerous policy challenges for even most stable democratic states." (Crocher 654) Globalization transcends territory, location, distance and borders, and has been accompanied by rapid migration of people across borders.

A striking feature in this age of globalization is the "transnational movement of people." Transnationalism has been defined as a "social process whereby migrants operate in social fields that transgress geographic, political and cultural boundaries."(Glick-Schiller 9).International migrants not only take their skills and expertise but also their culture and lifestyles with them. The internet, affordable airfare, and comparatively cheap overseas communication facilities have helped to maintain strong relationship with the homeland for most of the people who live outside their country of origin.

Human migration may be in the form of both voluntary migration within one's region, country, or beyond and involuntary migration which includes the slave trade, trafficking in human beings and ethnic cleansing.The term 'Diaspora' refers to the movement of any population sharing common ethnic identity that were either forced to leave from the nomadic culture or may be voluntary migration for better prospects and ultimately settling in a new geographic location. In referring to Modern Diasporas, Sheffer has proposed a simple definition: "Modern Diasporas are ethnic groups of migrant origins residing and acting in host countries but maintaining strong sentimental 
and material links with their country of origin- their homelands." (Sheffer 3) Diasporas keep a collective memory of their past and keep their links with the motherland alive. The initiatives of government of India like celebration of 'Pravsi Bhartiya Diavs' and Global Investors Summit boost the interaction of immigrants with the motherland.

Culture is a polysemic concept; it means different things to different people. A community is identified by its culture. The Oxford Dictionary of Philosophy describes the term culture as "The way of life of a people, including their attitudes, values, beliefs, arts, sciences, modes of perception and habits of thought and activity." Culture's growth, inheritance and transmission are through communication-in the form of language, symbols, literary and artistic forms.

Diaspora literature has emerged as a major area for studies of homeland. Although fiction is not any way just an extension of political theory, immigrant -writers with their focus on homeland, primarily deal with the fiction caused by disparate cultures. Canadian society is a multicultural society where all ethnic groups are recognized as equal in status. Writers of Indo-Canadian Diaspora have projected the dilemmas and the struggles of the Diaspora, thereby gave their ethnic existence a 'voice'.

\section{Cross Cultural Communication in Diaspora writing}

In the context of Canadian literary criticism, Victor Ramraj explains that diasporic writings "are invariably concerned with the individual's community's attachment to the centrifugal homeland" ( Ramraj 216). Like Homi Bhabha and Stuart Hall, Ramraj sees home as a discursively constructed category of diasporic writing and cultural belonging. Spivak is best known for her contemporary cultural and critical theories to challenge the "legacy of colonialism" and the way readers engage with literature and culture. She often focuses on the cultural texts of those who are marginalized by dominant western culture: the new immigrant; the working class; women; and other positions of the subaltern. Edward W. Saïd in his book Orientalism, makes a critical analysis of the culturally inaccurate representations that are the bases of Orientalism - the Western study of Eastern cultures; how The West perceives and represents The East. Edward Said's Orientalism seeks to study the post-colonial texts in the former 
colonies in the context of European imperialism. His concept of Orientalism is a Western Style for dominating, restructuring, heaving authority over the Orient. Edward Said and Gayatri Spivak emphasize culture and imperialism as the distinguished factors that influence post- colonial literature. Said was not against the West but he wants the West and the East to do away with the binary opposition between the West and the East so that one cannot claim superiority over the other. Said opines that since all cultures are hybrid and heterogeneous, the complete separation of the West from the East is well nigh impossible.

Among the most important figures in postcolonial feminism is Gayatri Spivak Chakravorty, who examines the effects of political independence upon "subaltern" or subproletarian women in the Third World. Spivak's subaltern studies reveal how female subjects are silenced by the dialogue between the male- dominated west and the maledominated east, offering little hope for the subaltern woman's voice to rise up amidst the global social institutions that oppress her.

Barbara Godard's essay “Notes from the Cultural Field: Canadian Literature from Identity to Hybridity" examines the ways in which contemporary global transformations have reshaped the dominant discourses of identity in Canadian literature and cultural theory. Godard suggests that although the geographical "imperative in Canadian literature discourses" persists, the "discursive constitution of space" is no longer performed within the boundaries of the Canadian nation-state (Godard 211). Instead, through their multiple national investments and subject-positions writers such as, Dionne Brand, Nino Ricci, Rohinton Mistry, Anita Rau Badami and Michael Ondaatje produce cross-cultural social imaginaries.

\section{Tell it to the Trees}

Badami's fourth novel Tell it to the Trees is focused on domestic drama about the impact of family secrets and the cost of preserving and protecting the family name. Tell it to the Trees is a story about a dysfunctional family of East Indian immigrants whose burden of secrets spells disaster for them and others. The story centers around the 
Dharma family, headed by Vikram Dharma who lives in the house that his father, Mr. J.K. Dharma, built years ago in the isolated wilds of Merrit's Point, British Columbia. Living with him are his mother- Akka, his second wife Suman, Varsha Dharma- 13 year old daughter of Vikram and his first wife Harini, and Hemant- the son of Suman and Vikram. Female voices are front and centre in Tell It to the Trees, as the suspenseful story unfolds from the multiple perspectives of 13-year-old Varsha, her stepmother Suman and Anu, who kept a notebook during her time living with the Dharmas. The events are recounted in the voices of Varsha, Suman, Hemant, and Anu Krishnan, the tenant. When Varsha was four, her mother Harini left her father and shortly afterwards she dies in an accident. Her father removes all evidence of Harini's existence in their lives, including pictures and all her personal belongings. Thus he sets the stage for the Varsha's determination not to ever lose someone again.

Eventually, Varsha's father travels to India and returns with a new wife, thirty year old Suman, who arrives in Canada six months after their marriage in India. She is quiet and not very pretty but she has a good heart and is willing to love Varsha. Suman learns almost immediately that Vikram is jealous, controlling and has a terrible temper. No matter what she does it is never good enough for Vikram, who demeans and abuses her and the children. She longs for her new husband to "love me into being." Anu embodies in-betweenness, a theme close to Badami's heart. She rents a cottage on the Dharmas' land, but is not a part of their family. Of Indian ancestry, she has been raised in the West and embraces contemporary values. As an outsider, she breaks through the Dharma family's boundaries, upsetting the precarious balance of their household, with tragic consequences. Vikram is only seen and heard through the eyes and ears of others. This novel explores many issues including those of arranged marriage, wife and child abuse, immigrants in Canada, and especially identity. Tell it to the Trees vividly portrays the increasing isolation of the Dharma family in the Merrit's Point community an isolation that is matched by Suman's isolation from the rest of this frightening family.

\section{Depiction of Canadian life in the Novel}


Badami narrates the physical situation and geographical condition of British Columbia region in Canada. It was 30 degrees below zero that night when dead body of the tenant Anu Krishnan found in the backyard of Dharma family house.

It was extremely cold there.

Vikram's wife Helen is killed in a car accident. Vikram feels shocked. Vikram then decides to go to India for the first time and in an arranged marriage, he then marries Suman. Six months later, Suman arrives at the Dharma house. Suman is so different from Helen. She is quiet and timid. She arrived from India full of promise of her new life, a new home, a new country and a daughter from Vikram's first marriage. Here, Badami depicts the issues of settlement by an immigrant in the alien land. Suman feels quite difference atmosphere in Canada and tries to adjust in the new environment both at home and outside.

Suman gives birth to a son named Hemant. Suman is a wonderful housekeeper and a wonderful cook, but Vikram finds fault with everything she does. He has a bad temper and begins to abuse her in the same way he did with his first wife. He calls her a fool and criticizes her for still wearing saris. Suman stops smiling and now she cries a lot. He even whips his daughter with his belt. The torture of a woman by her husband has been voiced by Badami through Suman's suffering. Vikram's mother tells Suman to leave and run as fast as she can to get away from her son. Varsha loves her stepmother and hides her passport so that she can't leave. With Anu's friendship with the two women, terrible things are bound to happen. Secrets are now slowly spilling out and that will cause more problems. Here Badami narrates how an immigrant has to adjust in a

new society.

\section{Portrayal of India in the Novel}

The novel is a domestic drama of family life set in an Indian household, about the impact of family secrets and the cost of preserving and protecting the family name. Suman, who journeyed from Madras, India, in a hastily arranged marriage, straddles two far-flung worlds. Though she dreams of running away from bleak and isolated Merrit's Point, she has nowhere to go. Gazing into the mirror she muses, "I. Such a sliver of a word to hold the meaning and the matter of all that I was and would be." She 
longs for her new husband to "love me into being." Anu embodies in-betweenness, a theme close to Badami's heart. She rents a cottage on the Dharmas' land, but is not a part of their family. Of Indian ancestry, she has been raised in the West and embraces contemporary values. Anu, as an outsider, breaks through the Dharma family's boundaries, upsetting the precarious balance of their household, with tragic consequences.

The novel of Anita Rau Badami represents the multi cultured society. It conceptualizes cross-fertilizations between Canadian literature and Diaspora studies and intervene into current discourses of Diaspora. Its theme is the ways in which the effects of environmental and economic global restructuring, along with the disintegration of received local forms of national and cultural identification, transform the micro spaces of social life.

\section{Conclusion}

Badami has depicted the culture of homeland India and hostland Canada. She has portrayed the life of people in India, patriarchal set up, caste based society, food, customs, religious practices etc. As an acclaimed writer of Diaspora, Badami also narrates incidences in Canada, the immigrants maintaining their cultural roots in an alien land as well as adapting the culture of Canada to adjust the life. The Diaspora novels transmits cultures of both the countries and thereby make the reader aware about the differences between the two cultures viz. of east and west and provide hint to understand the differences for harmony. 


\section{Works Cited}

Badami,Anita Rau. Tell it to the Trees. Canada: Vintage, 2012.Print.

Croucher,S."South Africa's Illegal Aliens: Constructing National Boundaries in a PostApartheid State". Ethnic and Racial Studies,21:639-660.1998.Print.

Glick-Schiller,N. Basch, L.and Blanc-Szanton,C.Towards a Transnational Perspective on

Migration: Race,Class, Ethnicity and Nationalism Reconsidered.New York Academy of Sciences: New York.1992.Print.

Godard, Barbara. "Notes from the Cultural Field: Canadian Literature from Identity to Hybridity." Essays on Canadian Writing72 (2000): 209-47.Print.

Martin,P. and Widren,J.n "International Migration : Facing the Challenge".Population Bulletin, Vol.57,No.1:1-40.2002.Print.

Ramraj, Victor. "Diasporas and Multiculturalism." New National and Postcolonial Literatures: An Introduction. Ed. Bruce King. Oxford: Clarendon, 1996.Print.

Sheffer, Gabriel, ed. Modern Diasporas in International Politics. London: Croom Helm, 1986.Print.

\section{Dr. Priyanki R Vyas \\ Librarian, LDRPITR, Associate Prof, Department of Library Science, BAOU, Ahmedabad India}

\&

Dr. Mahesh B Bhatt

Department of English, Government Science College, Idar

$\&$

Ms. Jill Joshi

C.U. Shah University 